\title{
Effect of a Benign Prostatic Hyperplasia (BPH) Xenobiotic - Croton membranaceus Müll.Arg. Root Extract on CYP1A2, CYP3A4, CYP2D6, and GSTM1 Drug Metabolizing Enzymes in Rat Model
}

George A. Asare ( $\nabla$ gasare@chs.edu.gh )

University of Ghana https://orcid.org/0000-0002-8002-5579

Royronald Ochieng Ongong'a

University of Ghana

Yvonne Anang

University of Ghana

Richard H. Asmah

University of Ghana

Habibur Rahman

Bangladesh Agricultural University

\section{Research}

Keywords: Croton membranaceus, phase I, and II metabolizing enzymes, prostate, BPH, Cytochrome p450

Posted Date: August 28th, 2020

DOI: https://doi.org/10.21203/rs.3.rs-55497/v1

License: (c) (1) This work is licensed under a Creative Commons Attribution 4.0 International License.

Read Full License 


\section{Abstract \\ Background}

Croton membranaceus Müll.Arg., root extract has been scientifically and clinically proven to be efficacious in the management of BPH. However, its effect on liver drug-metabolizing enzymes has not been established. This study aimed to determine the effect of the plant extract on phase I and phase II drug-metabolizing enzymes.

\section{Materials and methods}

Fifteen (15) castrated testosterone-induce BPH male Albino Wister rats weighing between 120-150 grams were randomly divided into 3 groups of 5 rats each (Groups II-IV). Five (5) uncastrated rats in Group I was used as a negative control, receiving only distilled water. Group II was administered $30 \mathrm{mg} / \mathrm{kg}$ b. wt extracts of C. membranaceus. Group III was the BPH-model group (administered distilled water) while Group IV was administered $0.5 \mathrm{mg} / \mathrm{kg} \mathrm{b}$. wt finasteride and was used as the positive control. $\mathrm{BPH}$ was induced in groups II-IV by administering testosterone propionate, $3 \mathrm{mg} / \mathrm{kg} \mathrm{b}$. wt for 28 days after a 7-day post castration rest period. Rats were euthanized and individual livers harvested for microsome preparation. The liver microsomes were assayed for, Phase I Drug Metabolizing Enzymes (DME); CYP1A2, CYP3A4, CYP2D6, and phase II; GST-M1 using Enzyme-Linked Immuno-Sorbent Assay (ELISA) techniques.

\section{Results}

Significant induction in phase I enzymes CYP1A2 was observed $(p=0.02)$, while CYP3A4 and CYP2D6 were inhibited $(0.00,0.01$, respectively). Phase II enzymes, GSTM1, showed a significant induced ( $p=$ 0.01). C.membranaceus induced CYP1A2 strongly, GSTM1 modestly, and had an inhibitory effect on CYP3A4/CYP2D6.

\section{Conclusion}

Croton membranaceus induces and inhibits some phase I metabolizing enzymes while moderately inducing phase II metabolizing enzymes. Care should be taken in the use of phytotherapy in conjunction with other drugs.

\section{Introduction}

Benign prostate hyperplasia (BPH), is a non-cancerous condition, characterized by the enlargement of prostate glands with hyperplasia of both the stromal and epithelial cells, leading to large distinct lumps in the prostate glands that culminates to lower urinary tract symptoms (LUTS) [1]. The real cause is not 
clearly understood; however, 5-a reductase hormone is suspected to play the central role in the pathogenesis by its ability to convert testosterone to Dihydrotestosterone (DHT), which is a powerful stimulator of prostate growth [2]. There is as yet no validated therapy for all men with symptomatic BPH. A third of patients never respond to medicinal therapy, and therefore opt for surgery [3].

The use of herbal medicine is wide-spread mostly in developing countries where it is accepted culturally and naturally as safer and the most efficient way of treatment and serves as the first level of contact for individuals and communities in the health care system [4]. The herbal drugs are used as monotherapy, in combination, or a drug-herb combination. However, little is understood about their toxic effects that may result in these interactions [5]. Combined phytotherapy is favored over monotherapy as being more potent without recourse to herb-herb interactions [6]. Herb-herb or herb-drug interaction can usually lead to unpredictable complications [7]. Croton membranaceus Müll.Arg. root extract has been scientifically and clinically proven to be efficacious in the management of BPH [8]. Different parts of the plant are commonly used to treat and manage other diseases as well. The leaves are significant in the treatment of digestion disorders and anorexia in Nigeria, while in Ghana it is mainly used in the management of BPH [9]. In vivo studies carried out indicate that the ethanolic extract is non-toxic and known to significantly inhibit the proliferation of glandular epithelial cells thus reducing the PSA and prostate volume $[10,11]$. Xenobiotic metabolizing enzymes formed in the liver ensures the elimination of xenobiotics through biotransformation from the body system [12]. The elimination is achieved through two phases [13], Phase I constitutes the largest family of membrane-bound, nonspecific mixed-function enzymes known as the CYP450 such as CYP1A1, CYP1A2, CYP2D6, CYP3A4, CYP2C19, CYP3A412 while the phase Il usually constitutes transferases and include, UDP-glucoronosyl transferases (UGTs), sulfotransferases (SULTs), N acetyltransferases (NATs), glutathione-s-transferases(GSTs) and various methyltransferases ${ }^{14}$.

\section{Materials And Methods}

\subsection{Plant extract}

The roots of $C$. membranaceus plants were collected from the Gyekiti forest reserve in the Eastern region of Ghana. The plant was identified in its vernacular name (Bokum) by the farmers and authenticated by taxonomists from the Center for Scientific Research into Plant Medicine (CSRPM) herbaria, where voucher specimens (CSRP 2110) of the plants have been kept for reference purposes. The roots were carefully and thoroughly washed and sun-dried for 2 weeks. Roots were later crushed into a fine powder and packed in specimen jars, labeled and stored at room temperature $\left(25 \pm 2^{\circ} \mathrm{C}\right)$. The roots were further squashed for 1 day with 4 liters of purified water and subjected to heat for 1 hour. The squashed root extract was filtered using sterile 4-fold gauze. Three (3) liters of water was subsequently added to the sediments, soaked for an additional 24 hour and the previous process was repeated to get another root extract. The extracts were combined, freeze-dried, and stored at $2-8^{\circ} \mathrm{C}$ until use.

\subsection{Experimental Animals}


Twenty (20) Wister albino rats were caged in stainless cages in groups of four (5) at the Animal Experimental Unit of the Bangladesh Agriculture University. Rats were maintained in a controlled environment of temperature $25 \pm 1^{\circ} \mathrm{C}, 51 \pm 2$ humidity, and a 12 hours light-darkness cycle. Rats were acclimatized for 7 days under the housing condition before the commencement of the experiment and were fed ad libitum standard chow diet (AIN-93G) formulation with a constant supply of water. The study was conducted under the internationally accepted principles for laboratory animal use and care. Animals were treated humanely.

Group I, the uncastrated negative control group was administered distilled water. All other groups were $\mathrm{BPH}$ induced by castration and testosterone ( $5 \mathrm{mg} / \mathrm{kg} \mathrm{b}$.wt. testosterone propionate subcutaneously) for 28 days after a 7- day recuperation period post castration. Group II was treated with $30 \mathrm{mg} / \mathrm{kg} \mathrm{b}$. wt. $C$. membranaceus extract. Group III was the model group (disease induced) with no treatment, while Group IV was treated with $0.5 \mathrm{mg} / \mathrm{kg}$ b. wt finasteride as a positive control. After 28 days rats were weighed, anesthetized with chloroform and blood drawn by cardiac puncture. After euthanization, the livers were excised and placed on tissue absorbent and rapidly weighed and frozen at $-20^{\circ} \mathrm{C}$. The prostate was also excised, weighed, and preserved in $10 \%$ neutral buffered formalin. The prostatic index was determined as follows: (prostate weight/body weight) x 100 .

\subsection{Isolation of microsomes from Rat frozen liver}

Liver microsomes were separated using the differential centrifugation method. One gram $(1 \mathrm{~g})$ frozen livers were placed on a glass plate and minced into small pieces by use of a sterile razor blade until a paste-like consistency was formed. The minced livers were put into a beaker containing $1 \mathrm{ml}$ of cold PBS (phosphate buffer solution). The livers were homogenized using a Dounce tissue grinder with cold PBS. On the ice, the tissue samples were homogenized with 50 strokes in $1 \mathrm{ml}$ of the phosphate buffer. Additionally, $1 \mathrm{ml}$ of the buffer was added to the homogenate, and then pipetted up and down, to completely suspend the homogenate. The homogenate was pipetted into microcentrifuge tubes and vortexed for 30 secs, followed by incubation on ice for $1 \mathrm{~min}$. and centrifugation at 3500 RPM for 15 min at $4^{\circ} \mathrm{C}$.

The supernatants were poured off, pellets re-suspended in $1 \mathrm{ml}$ buffer and spun at 10,000 RPM for 60 minutes at $4{ }^{\circ} \mathrm{C}$. The process was repeated and further spun at 15,000 RPM for 60 minutes at $4{ }^{\circ} \mathrm{C}$. Finally, the supernatants were discarded, and the remaining pellets re-suspended in homogenization buffer using Dounce tissue homogenizer $(1: 1 \mathrm{w} / \mathrm{v})$. The individual rats' homogenate was pooled for each group which later was used for each DME analysis.

\subsection{Determination of phase I and II metabolizing enzymes}

Kits from My BioSource (CA, USA) were used. The protocol was the same for all ELISA assays. In brief, the ELISA CYP1A2 kit was coated with monoclonal antibodies in the wells. Liver homogenate (containing the antigen) was introduced followed by a conjugate. After incubation, excess unbound antigens were washed with the wash buffer and blotted dry. This was followed by the addition of TMB solution to 
develop the chromogen. After incubation, the reaction was stopped by the addition of conc. $\mathrm{HCl}$ and the final chromogen read at $450 \mathrm{~nm}$. The same principles and procedure governed the rest of the assays except for the plates that differed by being coated with other antibodies (CYP3A4, CYP2D6, CYP2C9, GSTM1, GSTP1, and ARSG). All assays were carried out according to the manufacturer's instructions.

\section{Results}

\subsection{BPH induction}

$\mathrm{BPH}$ was successfully induced in the Model group as well as groups that received $C$. membranaceus and finasteride. The prostatic index of the model group was significantly different from that of the control group $(p=0.016)$ (Table 1). Furthermore, the prostatic index of the $C$. membranaceus (II) and finasteridetreated groups were significantly lower compared to the model group $(p=0.05$ and $p=0.031$, respectively).

Table 1

The prostatic index of the groups

\begin{tabular}{|llllll|}
\hline & $\begin{array}{l}\text { Mean body wt } \\
(\mathbf{g})\end{array}$ & $\begin{array}{l}\text { Mean prostate wt } \\
\mathbf{( g )}\end{array}$ & $\begin{array}{l}\text { Prostatic } \\
\text { Index }\end{array}$ & $\begin{array}{l}\text { P-Value } \\
\text { (C) }\end{array}$ & $\begin{array}{l}\text { P-Value } \\
\text { (M) }\end{array}$ \\
\hline Group I control & $128.8 \pm 8.6$ & $0.3 \pm 0.1$ & $0.23 \pm 0.89$ & 1.000 & 0.016 \\
\hline Group II Croton & $141.8 \pm 5.7$ & $0.5 \pm 0.1$ & $0.30 \pm 0.11$ & 0.119 & $0.050^{\beta}$ \\
\hline Group III Model & $145.3 \pm 8.1$ & $1.0 \pm 0.4$ & $0.69 \pm 0.26$ & $0.016^{*}$ & 1.000 \\
\hline $\begin{array}{l}\text { Group IV } \\
\text { Finasteride }\end{array}$ & $154.3 \pm 6.1$ & $0.5 \pm 0.2$ & $0.32 \pm 0.10$ & 0.080 & $0.031^{\beta}$ \\
\hline *when Pl of other groups are compared to the control group & & & \\
\hline
\end{tabular}

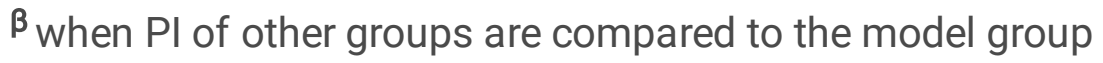

\subsection{Concentration of the Enzymes}

The mean \pm SEM for each phase I enzyme was calculated as shown in Table 2. CYP1A2 showed a statistical significance for groups I, II. CYP3A4 and CYP2D6 showed a statistical significance for all the groups while CYP2C9 showed no statistical significance for any of the groups. The Mean \pm SEM for phase II enzyme was calculated as presented in Table 3. GSTMI showed statistical significance for all the groups except the model group (group III). 
Table 2

The mean \pm SEM $(\mathrm{pg} / \mathrm{ml})$ for each enzyme in phase I was calculated as shown below. CYP1A2 showed a statistical significance for group I, II and group IV

\begin{tabular}{|lllllll|}
\hline & CYP1A2 & & CYP3A4 & & CYP2D6 & \\
\hline & $\begin{array}{l}\text { Mean } \pm \text { SEM } \\
(\mathbf{p g} / \mathrm{ml})\end{array}$ & $\begin{array}{l}\text { P- } \\
\text { Value }\end{array}$ & $\begin{array}{l}\text { Mean } \pm \text { SEM } \\
(\mathrm{pg} / \mathrm{ml})\end{array}$ & $\begin{array}{l}\text { P- } \\
\text { Value }\end{array}$ & $\begin{array}{l}\text { Mean } \pm \text { SEM } \\
(\mathrm{pg} / \mathrm{ml})\end{array}$ & $\begin{array}{l}\text { P- } \\
\text { Value }\end{array}$ \\
\hline Group I (Control) & $2313 \pm 121$ & $0.01 *$ & $52439 \pm 9157$ & $0.00 *$ & $12 \pm 1$ & $0.00 *$ \\
\hline Group II (Croton) & $3765 \pm 615$ & $0.01 *$ & $1708 \pm 345$ & $0.00 *$ & $5 \pm 1$ & $0.00 *$ \\
\hline $\begin{array}{l}\text { Group III } \\
\text { (Model) }\end{array}$ & $2569 \pm 30$ & 1.00 & $1266 \pm 412$ & $0.00 *$ & $7 \pm 0$ & $0.00 *$ \\
\hline $\begin{array}{l}\text { Group IV } \\
\text { (Finasteride) }\end{array}$ & $2645 \pm 83$ & 1.00 & $1264 \pm 111$ & $0.00 *$ & $7 \pm 0$ & $0.00 *$ \\
\hline *. The mean difference is significant at $\mathrm{p} \leq 0.05$ & & & & & \\
\hline
\end{tabular}

Table 3 The mean \pm SEM $(\mathrm{pg} / \mathrm{ml})$ of phase II enzyme GSTMI for each group.

The mean concentration and standard mean error of the enzyme were calculated and shown in the table. GSTMI showed statistical significance for all the groups except the model group.

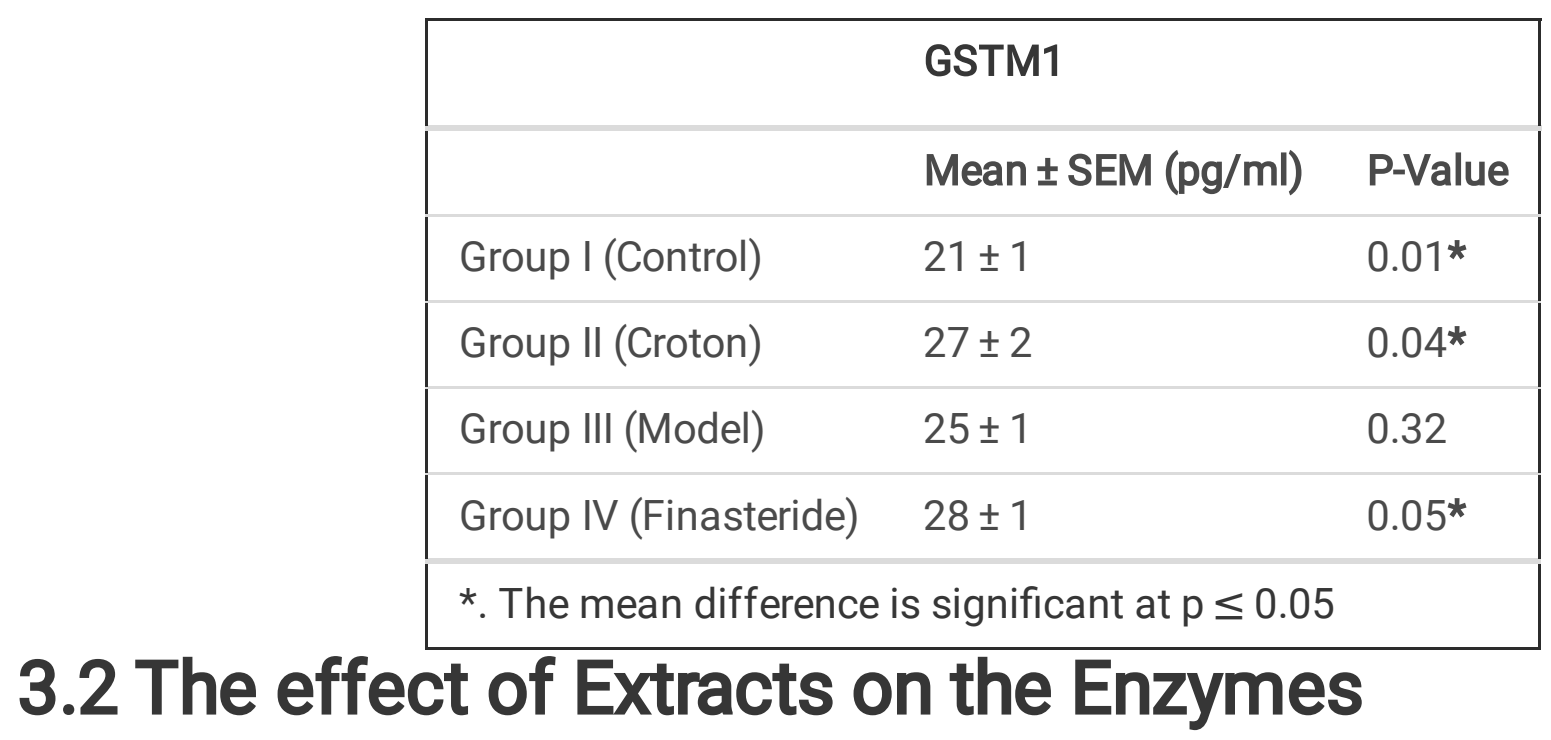

All the groups showed statistical significance with ANOVA for both phase I and phase II DME. The ANOVA result showed a statistically significant value of $p=0.002, p=0.00$, and $p=0.000$ for CYP1A2, CYP3A4, CYP2D6, respectively, in phase I drug-metabolizing enzymes (Table 4). The ANOVA result also showed a significance value of $p=0.001$ for GSTM1 phase II DME (Table 5). 
Table 4

Effect of various treatment on Phase I and Phase II drugmetabolizing enzymes

\begin{tabular}{|llllll|}
\hline \multicolumn{4}{|c|}{ Phase I DME } & \multicolumn{4}{c|}{ Phase II DME } \\
\hline F & P-Value & F & P-Value \\
\hline CYP1A2 & 4.971 & $0.002 *$ & GSTMI & 5.867 & $0.001^{*}$ \\
\hline CYP3A4 & 24.76 & $0.000 *$ & & & \\
\hline CYP2D6 & 16.461 & $0.000 *$ & & & \\
\hline
\end{tabular}

Table 5

Effect of various treatment on CYP1A2 enzyme

\begin{tabular}{|c|c|c|c|c|c|c|c|}
\hline $\begin{array}{l}\text { Dependent } \\
\text { Variable }\end{array}$ & & & $\begin{array}{l}\text { Mean } \\
\text { Difference }\end{array}$ & $\begin{array}{l}\text { STD } \\
\text { Error }\end{array}$ & $\begin{array}{l}\mathrm{p}- \\
\text { value }\end{array}$ & $95 \% \mathrm{Cl}$ & \\
\hline \multirow[t]{3}{*}{ CYP1A2 } & C & $\begin{array}{l}\text { CT (Group } \\
\text { II) }\end{array}$ & $-1452^{*}$ & 359.85 & 0.01 & -2646.05 & -258.01 \\
\hline & & $\underset{\text { III) }}{M}$ (Group & -255 & 340.82 & 1.00 & -1449.80 & 938.24 \\
\hline & & $\begin{array}{l}F(\text { Group } \\
\text { IV) }\end{array}$ & -331 & 349.81 & 1.00 & -1525.55 & 862.49 \\
\hline
\end{tabular}

Table 6

Effect of various treatment on CYP3A4 enzyme

\begin{tabular}{|c|c|c|c|c|c|c|c|}
\hline $\begin{array}{l}\text { Dependent } \\
\text { Variable }\end{array}$ & & & $\begin{array}{l}\text { Mean } \\
\text { Difference }\end{array}$ & $\begin{array}{l}\text { STD } \\
\text { Error }\end{array}$ & $\begin{array}{l}\text { p- } \\
\text { value }\end{array}$ & $95 \% \mathrm{Cl}$ & \\
\hline \multirow[t]{3}{*}{ CYP3A4 } & $C$ & $\begin{array}{l}\text { CT (Group } \\
\text { II) }\end{array}$ & $50730 *$ & 5030 & $0.00 *$ & 31168 & 70293 \\
\hline & & $\begin{array}{l}\text { M (II) } \\
\text { (Group }\end{array}$ & $51172^{\star}$ & 5731 & $0.00 *$ & 31609 & 70735 \\
\hline & & F (Group IV) & $51174^{*}$ & 5211 & $0.00 *$ & 31611 & 70737 \\
\hline
\end{tabular}

*. The mean difference is significant at $p \leq 0.05$

Post hoc Bonferroni test determined the specific differences of means among the treatment groups. CYP1A2 showed a significant value of $p=0.01$ for group II rats (Croton membranaceus extract). The rest of the groups did not show any significant differences for CYP1A2 (Table 5). Furthermore, CYP3A4 and CYP2D 6 showed a significant level of $p \leq 0.00$ in all the groups (Tables 6 and 7). 
Table 7

Effects of various treatment on CYP2D6

\begin{tabular}{|c|c|c|c|c|c|c|c|}
\hline \multicolumn{3}{|c|}{ Dependent Variable } & \multirow{2}{*}{$\begin{array}{l}\text { Mean Difference } \\
6.90^{\star}\end{array}$} & \multirow{2}{*}{$\begin{array}{l}\text { STD Error } \\
0.56\end{array}$} & \multirow{2}{*}{$\begin{array}{l}\text { p-value } \\
0.00^{*}\end{array}$} & \multicolumn{2}{|c|}{$95 \% \mathrm{Cl}$} \\
\hline \multirow[t]{3}{*}{ CYP2D6 } & $\mathrm{C}$ & CT (Group II) & & & & 3.90 & 9.91 \\
\hline & & M (Group III) & $5.15^{\star}$ & 0.88 & $0.00 *$ & 2.15 & 8.16 \\
\hline & & F (Group IV) & $5.15^{\star}$ & 0.83 & $0.00 *$ & 2.15 & 8.16 \\
\hline
\end{tabular}

Table 8

Effects of various treatments on GSTMI Enzyme. For phase II DME, multiple comparison Bonferroni post hoc test showed a significant level for GSTM1 at 0.04 for group II, 0.00 for Group IV

\begin{tabular}{|c|c|c|c|c|c|c|c|}
\hline $\begin{array}{l}\text { Dependent } \\
\text { Variable }\end{array}$ & & & $\begin{array}{l}\text { Mean } \\
\text { Difference }\end{array}$ & $\begin{array}{l}\text { STD } \\
\text { Error }\end{array}$ & p-value & $95 \% \mathrm{Cl}$ & \\
\hline \multirow[t]{3}{*}{ GSTM1 } & $C$ & $\begin{array}{l}\text { CT (Group } \\
\text { II) }\end{array}$ & $-6.08^{\star}$ & 1.44 & $0.04^{*}$ & -12.02 & -0.13 \\
\hline & & M (Group III) & -4.58 & 1.70 & 0.32 & -10.52 & 1.37 \\
\hline & & F (Group IV) & $-7.58 *$ & 1.74 & $0.00 *$ & -13.52 & -1.63 \\
\hline
\end{tabular}

Table 9. Effect on CYP1A2 using the model (M) group as the baseline.

C. membranaceus (Group II) significantly increased CYP1A2 ( $p=0.0001)$ using the model group as the baseline, whereas finasteride (Group IV) did not.

\begin{tabular}{|lll|}
\hline CYP1A2 & Mean \pm SEM & P-Value \\
\hline M (Group III) & $2569 \pm 30$ & \\
\hline CT (Group II) & $3765 \pm 615$ & $0.01^{*}$ \\
\hline F (Group IV) & $2645 \pm 83$ & 0.54 \\
\hline C (Group I) & $2313 \pm 121$ & $<0.01^{*}$ \\
\hline
\end{tabular}

Considering the model group as a baseline, significant differences were seen for the Control (Group I) and CT (Group II) with regard to CYP1A2 ( $\mathrm{p}=0.0001$ and $\mathrm{p}<0.0001$ prospectively) (Table 9). 
Table 10

Effect on GSTM1 using the model (M)

group as the baseline. Finasteride

demonstrate significant increase in GSTM1

$(p=0.05)$

\begin{tabular}{|lll|}
\hline GSTMI & Mean \pm SEM & P-Value \\
\hline M (Group III) & $25.2 \pm 0.6$ & \\
\hline CT (Group II) & $36.8 \pm 1.7$ & 0.46 \\
\hline F (Group IV) & $28.3 \pm 1.2$ & $0.05^{\star}$ \\
\hline C (Group I) & $25.5 \pm 0.5$ & 0.08 \\
\hline
\end{tabular}

For GSTM1 only Group IV showed statistical difference with the model group as a baseline $(p=0.05)$ (Table 10).

Table 11

Enzymatic activity change as a percentage (\%) of the control group (Group I)

\begin{tabular}{|lllll|}
\hline & CYP1A2 & CYP3A4 & CYP2D6 & GSTM1 \\
\hline C (Group I) & 0 & 0 & 0 & 0 \\
\hline CT (Group II) & +62 & -80 & -46 & +30 \\
\hline M (Group III) & +44 & -90 & -43 & +22 \\
F (Group IV) & +12 & -94 & -38 & +36 \\
\hline
\end{tabular}

\section{Discussion}

The use of medicinal plants globally continues to grow [15]. It is not only an issue in lower-income countries due to the lack of accessibility to the orthodox health care system but also in middle and highincome countries, its use is considered prestigious where the medical plant has been well researched and tested [4]. In America, about 30\% will resort to the use of Saw palmetto for prostate and LUTS disorders [16]. In Austria and Germany, as many as $90 \%$ of men prefer phytotherapy for prostate disorders [17]. In Ghana and some African countries, the use of $C$. membranaceus for prostate disorders continues to grow [18]. Not only do people seek it's exclusive it but also in combination with orthodox medicine and other medicinal plants [19]. C. membranaceus has been shown to inhibit BPH-1 cell proliferation [8]. However, studies have not been undertaken to evaluate the effect of the plant extract on DMEs.

The construction of the BPH animal model was to provide answers to the pathological condition, rather than the use of a normal animal model. Data has demonstrated that $C$.membranaceus is specifically prostate targeting among the various organs [9]. The experimental design that was steroid-based included a model (the model group - III) that was not treated with the extract to demonstrate the direct 
effect of the BPH castration-steroid model on DMEs. Furthermore, to compare the effect of the extract as a medicinal plant as against the conventional drug, a finasteride control model was also included.

In light of this holistic experimental design, careful interpretation is given to the data. The effect of CYP3A4 on the various drug, drug-herb, drug-herb-herb administrations remained the same in all groups. Testosterone was administered to maintain the prostate enlarged throughout the experiment. However, the effect on this procedure did not show any disadvantage as the model group (group III) had levels that were as low as the Finasteride group (group IV) of which no difference existed between the two. There was therefore a significant lowing in all the groups compared to the control group. There was a 31-41x reduction in CYP3A4 in all groups compared to the control group. The metabolism of testosterone to DHT is CYP450 dependent [20].

Endogenous testosterone is metabolized by the body and is not an inhibitor of CYP450. The administration of testosterone in this model does appear to have affected CYP3A4. However, post hoc analysis demonstrated that the finasteride and the plant extract significantly inhibited the CYP3A4 (Table 6). CYP3A4 may be highly expressed under normal conditions but suppressed in disease states. For example, CYP450 3A5 is highly expressed in normal human prostate cells is much lower in the disease state [21].

Fifty-seven (57) plant extracts used in Traditional Chinese Medicine have been reported to inhibit CYP3A4 activity ${ }^{22}$ Similarly, PC-SPES a multiherbal preparation (8 plants) for prostate cancer has been shown to inhibit CYP3A4 expression and activity ${ }^{23}$. CYP3A4 inhibition seen in this study could, therefore, be due to both disease and medication although CT appears to have slightly less inhibitory effect compared to the others test groups (Table 2).

CYP2D6 activity was inhibited in the same manner as CYP3A4 with an inhibition of 38 to $46 \%$ (Table 11). The main function of CYP2D 6 is metabolizing and eliminating as much as $25 \%$ of drugs of clinical use. Bush mint (Hyptis suaveolens) and spreading hogweed (Boerhavia diffusa) medicinal plant extracts differentially affect activities of CYP2D6; and the crude aqueous extracts inhibits DMEs CYP2D6 in a reversible and time-dependent manner [23].

Not only do medicinal plants inhibit CYP450, but some fruits and juices also have similar potentials [24]. Four (4) out 15 of traditional preparations and methanol extracts of medicinal plants from Papua New Guinea exhibited a similar Cytochrome P450 inhibitory effect on CYP2D6. Besides, drug interactions with Saw palmetto (Serenoa repens) have been reported. Saw palmetto has been shown to potently inhibit CYP2D6 in vitro [25]. However, a clinical study with Saw palmetto reported no significant effect on CYP1A2, CYP2D6, CYP2E1 or CYP3A4 activity during supplementation for 28 days [26, 27].

CYP1A2 was the only phase 1 DME that showed a different trend by increasing. CYP1A2 metabolizes various environmental procarcinogens, such as heterocyclic amines, nitrosamines, and aflatoxin $B_{1}[28]$. Cigarette smoke increases CYP1A2 activity in humans. ${ }^{29}$ Cruciferous vegetables and well-cooked meat also increase CYP1A2 activity however, certain drugs and diets have been associated with reduced 
CYP1A2 activity in vivo [29]. Extracts of Bowiea volubilis and Spirostachys Africana are known to have inhibitory activity on CYP1A2 when the crude aqueous extract is incubated with hepatic microsomes [30]. B. monnieri used for improving memory and anxiety reduced the catalytic activities of CYP3A4, CYP2C9, and CYP2C19 to less than 10\% compared to the total activity [31]. Recent use of kratom (Mitragyna speciosa) a native herb of Southeast Asia as a recreational drug because of its psychoactive properties is of concern because a few reports available indicate that kratom affects CYP450 activities [32]. Others such as the aqueous and ethanol extract of $Z$. jujuba have been shown to increase CYP1A mediated conversion of phenacetin to acetaminophen [29].

Phyllanthus amarus a herb in Euphorbiaceae family is broadly considered as a hepatoprotective and hypoglycaemic agent by traditional practitioners as well as conventional researchers is known to considerably inhibit CYP1A2 and CYP2C9 across a range of concentrations [33-35].

CYP1A2 is important for the metabolism of endogenous substrates [36] and activation of many environmental carcinogens including dietary heterocyclic amines, certain mycotoxins, tobacco-specific nitrosamines, and aryl amines [28]. It has been suggested that sustained induction of CYP1A2 for example, maybe beneficial in women, as through 2-hydroxylation it increases estrogen clearance to antioestrogenic metabolites, so acting to protect against estrogen-driven tumors [37].

In this study, GSTM1 was significantly elevated in all groups apart from the model group. Hence, elevations will be purely due to the plant extract or in the case of group IV, finasteride. Induction of this enzyme was highest in group II. The basic function of the GSTM class of enzymes is in the detoxification of electrophilic compounds, including carcinogens, environmental toxins, and oxidative stress agents as well as therapeutic drugs, by conjugation with glutathione [37]. An induction in GSTM1 is useful as it will metabolize and conjugate carcinogens. GSH binding reduces the toxicity and increases the solubility of the toxic compound enhancing its excretion from the cell ${ }^{37}$. Medicines or diet components that enhance GST expression may assist in cancer prevention because maintaining a high and constant level of GST attenuates the effects of carcinogenic compounds [38]. Conversely, when GSTM1 hydrolyzes cancer chemotherapeutics or activates the anti-apoptosis pathway cancer drug resistance is induced through activation of autophagy [38].

\section{Conclusion}

Croton membranaceus induces CYP1A2 and inhibits CYP3A4 / CYP2A6 phase I metabolizing enzymes, while moderately inducing GSTM1phase II metabolizing enzyme. Care should be taken in the use of this phytotherapic drug in conjunction with other drugs.

\section{Declarations}

\section{Ethics approval:}


The study was approved by the Ethics and Protocal Review committee of the school of biomedical and allied health sciences,University of Ghana. Ethics identification number SBAHS-

MD./10556975/AA/5A/2016-2017.The study complied with the Helsinki Declaration of 1964 revised in 2018 ,on the use of animals for experimental studies.

\section{Consent for publication}

Not Applicable

\section{Availability of Data and Materials}

Please contact Author for Data Request

\section{Funding}

\section{Not Apllicable}

\section{Declaration of Conflicting Interests}

The author(s) declares that they have no potential conflict (s) of interest to the research, authorship, and/or publication of this article.

\section{Contribution of each author:}

G.A. conceptualized the study, was responsible for drug and extract administration, manuscript writing; R.O. performed laboratory analysis; Y.A. performed statistical and laboratory analysis; R.H.A. contributed to manuscript writing; H.R. built BPH model and contributed to manuscript writing.

\section{Aknowledgement}

Not applicable

\section{References}

1. Lloyd GL, Jeffrey M, Marks WAR. Benign Prostatic Hyperplasia and Lower Urinary Tract Symptoms: What is the Role and Significance of Inflammation? Physiology \& Behaviour. 2017;139-148.

2. English RS. A hypothetical pathogenesis model for androgenic alopecia: Clarifying the dihydrotestosterone paradox and rate-limiting recovery factors. Med Hypotheses. 2018;111:73-81.

3. Chung ASJ, Woo HH. Update on minimally invasive surgery and benign prostatic hyperplasia. Asian J Urology. 2018; 22-27.

4. Ozioma J, Chinwe ANO. Herbal Medicines in African Traditional Medicine. Herbal Medicine. 2019. DOI:10.5772/intechopen.80348. 
5. Chugh NA, Bali S, Koul A. Integration of botanicals in contemporary medicine: roadblocks, checkpoints, and go-ahead signals. Integrative Medical Research. 2018;109-125.

6. Lopes CM, Dourado A, Oliveira R. Phytotherapy and Nutritional Supplements on Breast Cancer. Biomedical Research International. 2017.

7. Kahraman C, Ceren AZ, Cankaya IT. The Clinical Importance of Herb-Drug Interactions and Toxicological Risks of Plants and Herbal Products. Medical Toxicology. 2020. 1-31.

8. Afriyie DK, Asare GA, Bugyei K, Adjei S, Lin JM, Peng J, Hong ZF. Treatment of benign prostatic hyperplasia with Croton membranaceus in an experimental animal model. J Ethnopharmacology. 2014;157:90-8.

9. Maroyi A. Review of Croton membranaceus Mûll. Arg.: phytochemical, pharmacological, and toxicological perspective. J Complementary Medical Research. 2018;9:24.

10. Asare GA, et al. Acute toxicity studies of Croton membranaceus root extract. J. Ethnopharmacology. 2011. 134;938-943.

11. Afriyie DK, et al. Treatment of benign prostatic hyperplasia with Croton membranaceus in an experimental animal model. J. Ethnopharmacology. 214. 157; 90-98.

12. Zanger UM, Schwab M. Cytochrome P450 enzymes in drug metabolism: Regulation of gene expression, enzyme activities, and impact of genetic variation. Pharmacol Ther. 2013;138:103-41.

13. 10.1016/B978-0-12-802104-0.00027-5

Stanley LA. Drug Metabolism. Pharmacognosy: In Fundamentals, Applications, and Strategy (Elsevier Inc., 2017). Pp 527-545. DOI:10.1016/B978-0-12-802104-0.00027-5.

14. Jancova P, Anzenbacher P, Anzenbacherova E. Phase II drug-metabolizing enzymes. Biomedical Papers. 2010;154:103-16.

15. Salmerón-Manzano E, Garrido-Cardenas JA, Manzano-Agugliaro F. Worldwide research trends on medicinal plants. International J Environmental Research. 2020. Public Health 17.

16. Fagelman E, Lowe FC. Saw Palmetto Berry as a Treatment for BPH. Reviews of Urology. 2001;3(3):134-8.

17. Curtis NJ, Shoskes D, Roehrborn CG, Moyad M. Nutraceuticals in Prostate Disease: The Urologist's Role. Reviews of Urology. 2008;10:192-206.

18. Kyei MY, Klufio GO, Ayamba A, Mohammed S. Traditional medicines and alternative practice in the management of prostate diseases in southern Ghana. Ghana Medical Journal. 2017;51:128-37.

19. Appiah AA, et al. Prospects of croton membranaceus for prostate Health. ACS Symposium Series. 2013. 1127; 79-92.

20. Swerdloff RS, Dudley RE, Page ST, Wang C, Salameh WA. Dihydrotestosterone: Biochemistry, physiology, and clinical implications of elevated blood levels. Endocrinology Reviews. 2017;38:22054.

21. Leskelä S, et al. Cytochrome P450 3A5 is highly expressed in normal prostate cells but absent in prostate cancer. Endocrinology Related Cancer. 2007;14:645-54. 
22. Ashour ML, Youssef FS, Gad HA, Wink M. Inhibition of cytochrome P450 (CYP3A4) activity by extracts from 57 plants used in traditional Chinese medicine (TCM). Pharmacognosy Magazines. 2017;13:300-8.

23. Wadsworth T, Poonyagariyagorn H, Sullivan E, Koop D, Roselli CE. In vivo effect of PC-SPES on prostate growth and hepatic CYP3A expression in rats. J of Pharmacology Experimental Therapeutics. 2003;306:187-94.

24. Mallhi TH, et al. Effect of Fruit / Vegetable-Drug Interactions on CYP450, OATP, and p-Glycoprotein: A Systematic Review. 2015. 14;1927-1935.

25. Yale SH, Glurich I. Analysis of the inhibitory potential of Ginkgo biloba, Echinacea purpurea, and Serenoa repens on the metabolic activity of cytochrome P450 3A4, 2D6, and 2C9. J of Alternative Complementary Medicine. 2005;11(3):433-9.

26. Gurley BJ, Fifer EK, Gardner Z. Pharmacokinetic herb-drug interactions (Part 2): Drug interactions involving popular botanical dietary supplements and their clinical relevance. Planta Med. 2012;78:1490-514.

27. Markowitz JS, et al. Multiple doses of saw palmetto (Serenoa repens) did not alter cytochrome P450 2D6 and 3A4 activity in normal volunteers. Clin Pharmacol Ther. 2003;74:536-42.

28. Shimada T. Inhibition of carcinogen-activating cytochrome P450 enzymes by xenobiotic chemicals in relation to antimutagenicity and anticarcinogenicity. Toxicology Research. 2017;33:79-96.

29. Hukkanen J, Jacob P, Peng M, Dempsey D, Benowitz NL. Effect of nicotine on cytochrome P450 1A2 activity. British J Clinical Pharmacology. 2011;72:836-8.

30. Fasinu PS, Bouic PJ, Rosenkranz B. An overview of the evidence and mechanisms of herb-drug interactions. Frontiers of Pharmacology. 2012. 1-19.

31. Ramasamy S, Kiew LV, Chung LY. Inhibition of human cytochrome P450 enzymes by Bacopa monnieri standardized extract and constituents. Molecules. 2014;19:2588-601.

32. Veltri C, Grundmann O. Current perspectives on the impact of Kratom use. Substance Abuse Rehabilitation. 2019;10:23-31.

33. Mishra P, Samanta L. Oxidative stress and heart failure in altered thyroid states. The Scientific World Journal. 2012. 741861.

34. Appiah-Opong R, Commandeur JNM, Axson C, Vermeulen NPE. Interactions between cytochromes P450, glutathione S-transferases and Ghanaian medicinal plants. Food Chem Toxicol. 2008;46:3598-603.

35. Antihyperglycemic effect and. antioxidant potential of Phyllanthus niruri (Euphorbiaceae) in streptozotocin induced diabetic rats. European Bulletin Drug Research. 2005;13:1-9.

36. Mazerska Z. Metabolism of chemical carcinogens. Carcinogenesis Anticarcinogensis in Food Components. 2005;21:37-67.

37. Sampson JN, Falk RT, Schairer C, et al. Association of Estrogen Metabolism with Breast Cancer Risk in Different Cohorts of Postmenopausal Women. Can Res. 2017;77(4):918-25. 
38. Pljesa-Ercegovac M, Savic-Radojevic A, Matic M, et al. Glutathione Transferases: Potential Targets to Overcome Chemoresistance in Solid Tumors. International J Molecular Science. 2018;19(12):3785. 